\author{
Tomasz STUDZIENIECKI, Ph.D. \\ Faculty of Entrepreneurship and Quality Science, Gdynia Maritime University \\ e-mail: tomaszstudzieniecki@wp.pl
}

DOI: $10.15290 /$ ose.2016.05.83.05

\title{
THE DETERMINANTS OF EGTC DEVELOPMENT IN POLAND
}

\begin{abstract}
Summary
A comprehensive interpretation of the European Grouping of Territorial Cooperation (EGTC) requires interdisciplinary studies, with particular focus on economic aspects. An EGTC is an innovative legal instrument of the EU and an economic tool developed to improve cross-border, transnational and interregional cooperation. Fifty EGTCs had been established in Europe by the end of 2014, including 3 EGTCs in Poland.

The aim of this article is to indicate and discuss the key determinants of development of such institutions, as well as to point out barriers and present proposals to overcome them. The operation of Polish groupings in view of European ones was discussed in this article. A working model describing internal and external determinants was developed. In the context of cohesion policy, it was proved that objectives and tasks of the groupings are coincident with the objectives of the European Territorial Cooperation. Previous original studies on EGTC development in Europe were used. Legal documents were analysed, a survey and interviews with directors of EGTCs were conducted in 2015.
\end{abstract}

Key words: cooperation, European, territorial, cross-border, EGTC

JEL: F15

\section{Introduction}

The European Grouping of Territorial Cooperation EGTC, hereinafter referred to as the EGTC, is a breakthrough economic, political and legal instrument. Its introduction has begun a new stage in the UE cohesion policy. This instrument has greatly improved cross-border, transnational and interregional cooperation, contributing to the strengthening of the social and economic cohesion (and recently territorial cohesion as well) of the areas which use this instrument.

However, numerous barriers, which slow down the development of EGTCs, limiting the full use of the potential of this tool, occurred. This also concerns Poland, where three European groupings exist and another two are being established.

The development of territorial cooperation prior to establishing the EGTCs in Poland is documented by relatively rich literature resources; however, a relatively low number of 
studies were dedicated to a comprehensive assessment of cooperation outcomes in the social, economic and spacial dimension [Dołzbłasz, Raczyk, 2010, p. 10].

The publications on EGTCs are relatively poor. This mainly results from the lack of access to source materials related to EGTCs in Europe. Most Polish studies on EGTCs were made when these organisations were only being established. In the meantime EU and national legislation was changed. In Poland the EGTC activities have been analysed mainly in legal [Kusiak-Winter, 2011; Kentnowska, 2012, pp. 234-250; Buczkowski, Żukowski, 2014, pp. 13-83] and political science terms [Adamczuk, 2014, pp. 13-20; Ruszkowski, 2010, pp. 269-276; Lewkowicz, 2013, pp. 43-70], and less frequently in economic terms [Jóskowiak, 2013, pp. 18-28].

It should be pointed out that, unlike the system research, a detailed analysis of the determinants of development is possible in respect of Poland. The author managed to obtain all the necessary documents and establish priceless cooperation with the EGTC authorities. The concept of the research proposed by the author may be used for more comprehensive identification of strengths and weaknesses, as well as opportunities and threats of the EGTC development in the European Union.

\section{The history and core of EGTCs}

The functioning of the EGTC as an instrument of cohesion policy refers to issues concerning local and regional development. Furthermore, through direct connections and associations with territorial cooperation in the borderlands, it also refers to issues concerning European integration [Pancer-Cybulska, 2015, pp. 383-393; Ładysz, 2011, pp. 30-40]. Europe has always been diverse in terms of social and economic development of its states and regions [Schoutheete, 1999, p. 99]. The border areas were in a particularly difficult situation [Kasprzyk, 2004, p. 25; Toczyski, Sartorius, Zaucha, 1997, p. 65]. Therefore, the improvement of social and economic cohesion became one of the priorities of the European regional policy [Proniewski, 2008, p. 296]. It was necessary to develop systemic solutions limiting or removing the key barriers in the crossborder, transnational and interregional cooperation. For this purpose, at the end of the 20th century "non-sovereign, territorial units" [Mikołajczyk, 2005, p. 297] were given an opportunity to enter into direct contacts with their foreign counterparts. New regulations and institutions were favourable to the development of international cooperation at local and regional level [Toczyski, Sartorius, Zaucha, 1997, p. 94-109; Dumała 2009, p. 31; Dołzbasz, Raczyk, 2010, pp. 204-206].

From an economic point of view, institutions which operate properly generate "added value" [Luks, 2012, p. 126] and help in accelerating social and economic development. EGTCs have become such institutions [Adamczuk, 2014, pp. 13-20]. Regulations provided them with legal personality, status and competencies unknown in the current history of the European Union [Studzieniecki, 2015, p. 15; Pancer-Cybulska, 2015, pp. 383-393]. European groupings rely on the experience and achievements of Euroregions [Jóskowiak, 2013, p. 28; Mędza, 2014, pp. 281-], which despite the lack of legal personality have become important entities of international relations [Lewkowicz, 2013, p. 47]. 
Many European Euroregions have been transformed into groupings since provisions enabling the establishment of an EGTC entered into force. Poland's Euroregions were provided with three options [Mędza, 2014, pp 291-291]:

1. to establish an EGTC based on an Euroregion;

2. to establish an EGTC without liquidating an Euroregion;

3. to abandon the establishment of an EGTC and continue operating as an Euroregion.

Transformation into an EGTC was taken consideration, for example, by the Nysa Euroregion [Mędza, 2014, pp. 288-292] and Sprewa-Nysa-Bóbr [Ślusarz, 2014, p. 38]. However, most Polish Euroregions (in particular, these located at the EU external borders) decided to keep their current status. It should be stressed that the EGTC instrument did not provide membership of entities outside the EU until 2013. Even after amending legislation, the establishment of an EGTC with entities outside the EU will be a challenge that requires not only a good political will but also an introduction of implementing provisions in national law.

\section{Concepts and tools to study EGTCs}

A comprehensive interpretation of the EGTC mechanism requires interdisciplinary research with particular focus on economic aspects (Figure 1). EGTCs are a tool mainly for economic and social objectives. Literature study and the analysis of the operation of all the European groupings in the European Union allowed to develop a working model describing the determinants of EGTC development. The determinants were divided into internal, dependent on the EGTC members themselves, and external, dependent on the most important entities determining the territorial cooperation, i.e. the European Union and the states from which the members of a grouping come from Resources and regulations were distinguished among the most significant factors of EGTC development.

EGTCs are a tool mainly for economic and social objectives. Literature study and the analysis of the operation of all the European groupings in the European Union allowed to develop a working model describing the determinants of EGTC development. The determinants were divided into internal, dependent on the EGTC members themselves, and external, dependent on the most important entities determining the territorial cooperation, i.e. the European Union and the states from which the members of a grouping come from Resources and regulations were distinguished among the most significant factors of EGTC development.

The resources are mostly external funds (such as funding from the ETC programmes), and, to a lesser extent, internal funds (from fees). The legal determinants (Figure 2.) of the operation of EGTCs are complex. EGTCs operate simultaneously based on the EU and national regulations. Internal documents are drawn up based on these regulations. Practically, the provisions of the states from which members join an EGTC have indirect influence on the EGTC organisation as well. 
FIGURE 1.

Model describing the determinants of EGTC development

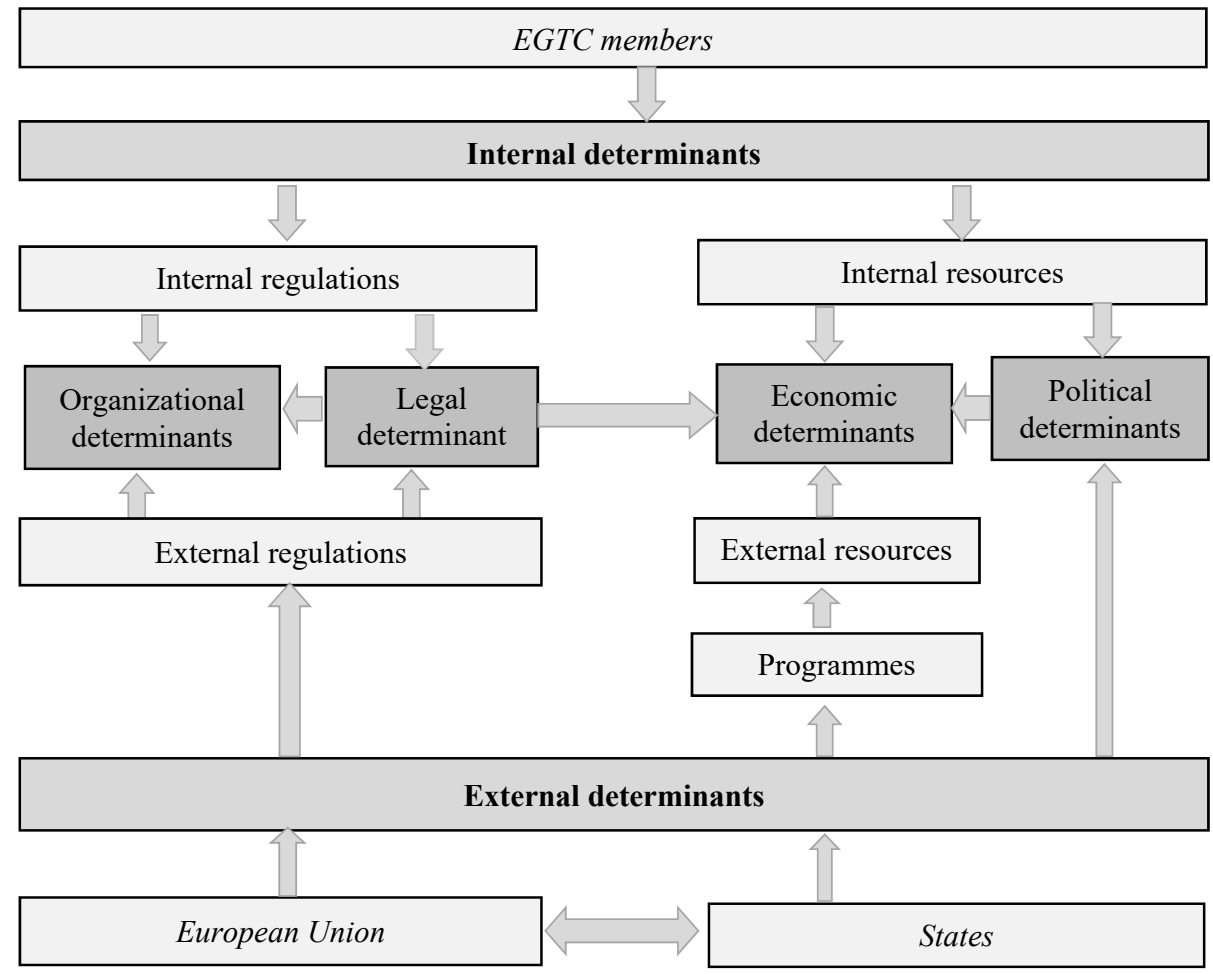

Source: own work

FIGURE 2.

Legal determinants of EGTC development

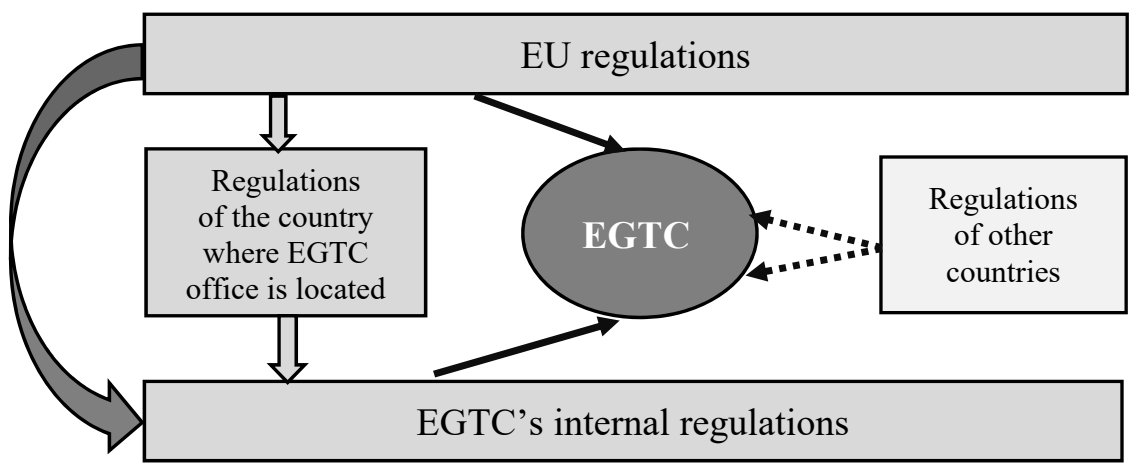

Source: own work 
The study on the Polish EGTCs has an advantage over the study of other groupings as more comprehensive comparison between theory and practice is available. In order to make such comparison, a questionnaire taking into account the key determinants of development was prepared.

\section{The operation of EGTCs}

The first EGTC was established in 2008. In Europe 50 EGTCs were registered by the end of 2014. Most of them (19) were set up in Hungary, the least (1) in Sweden and Bulgaria. In total, nineteen states have made use of the EGTC instrument. The instrument did not arise interest in the UK and Scandinavia. The EGTC members are mainly local government units. The number of EGTC members varies between 2 to 188. The number of all EGTC members is 780 .

Most of the groupings (32) were established for an unlimited period of time. Other groupings were set up for a period from 6 to 50 years. Concerning their area, the groupings can be divided into:

1. small (up to $1000 \mathrm{~km}^{2}$ ) $-32 \%$ of the EGTCs;

2. medium (more than $1000 \mathrm{~km}^{2}$ up to $10000 \mathrm{~km}^{2}$ ) $-24 \%$ of the EGTCs;

3. large (up to $10000 \mathrm{~km}^{2}$ ) $-44 \%$ of the EGTCs.

The institution which coordinates and promotes the EGTC development in Europe is the Committee of the Regions. The Association of European Border Regions also plays an important role. Its members are both Euroregions and EGTCs. Three EGTCs operate in Poland (Figure 3.). They are not interested in joining the Association.

\section{EGTCs in Poland}

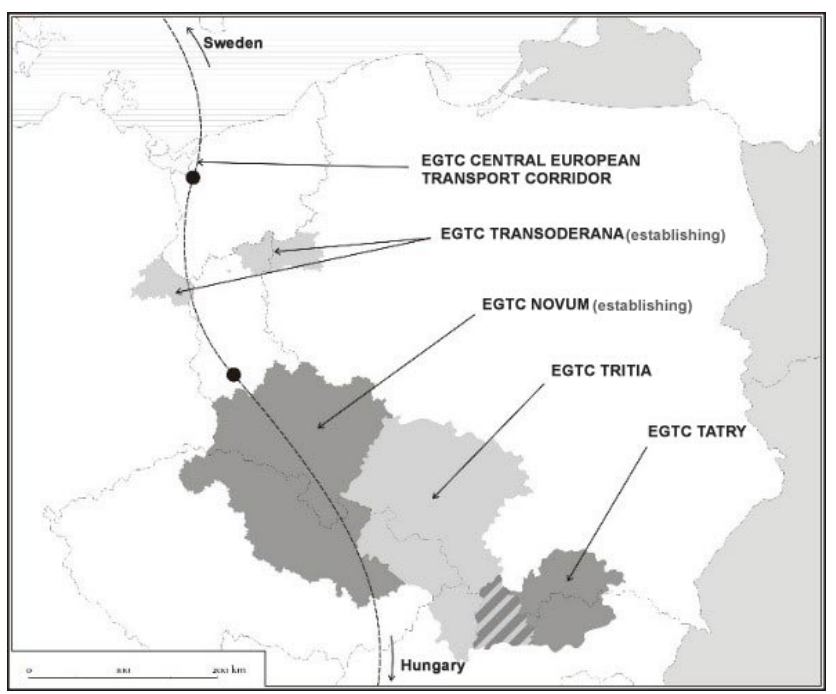

Source: own work. 
They were established between 2013 and 2014. The process of institutionalisation for many European EGTCs was long and tedious because it required consultations and consent of as many as four departments.

Concerning the EGTC Tatry, a difficulty arose of the requirement for another documents to be approved by the supreme bodies of both members-founders (Congresses), despite the fact that the amendments in those documents, which were required by the MFA, did not concern substantive issues and did not amend the core provisions of internal documents (Convention and Statute). On the other hand, determining the final contents of internal documents posed an issue for the ETC ŚKT (Środkowoeuropejski Korytarz Transportowy) due to divergent legal interpretation in the founding states.

Only the EGTC Tritia founders did not encounter any difficulties when registering their EGTC. A detailed description of the determinants in view of the conducted survey (Table 1.) was discussed in the further part of this article.

TABLE 1.

\section{The determinants of EGTC development in Poland in view of the survey}

\begin{tabular}{|c|c|c|c|c|}
\hline No. & Issue & EGTC ŚKT & EGTC Tatry & EGTC Tritia \\
\hline 1. & Difficulties during registration & Yes & Yes & No \\
\hline 2. & The 2014 budget & PLN 231385 & PLN 52593.40 & PLN 279203 \\
\hline 3. & $\begin{array}{l}\text { Number of personnel employed } \\
\text { by the EGTC in } 2014\end{array}$ & 0 & 0 & 4 \\
\hline 4. & Establishing problem committees & No & No & No \\
\hline 5. & Managing the ETC programme & No & No & No \\
\hline 6. & Managing the Small Projects Fund & No & No & No \\
\hline 7. & $\begin{array}{l}\text { Intention to join the Association } \\
\text { of European Border Regions }\end{array}$ & No & No & I do not know \\
\hline 8. & $\begin{array}{l}\text { Usefulness of the EGTC platform } \\
\text { of the Committee of the Regions }\end{array}$ & Yes & Yes & No \\
\hline 9. & $\begin{array}{l}\text { Implementation of the projects } \\
\text { funded from the EU funds }\end{array}$ & Yes & No & Yes \\
\hline 10. & $\begin{array}{l}\text { Preparation of development } \\
\text { strategy }\end{array}$ & $\begin{array}{l}\text { Intended to } \\
\text { prepare }\end{array}$ & Yes & Yes \\
\hline 11. & Plans to accept new members & Yes & No & No \\
\hline 12. & $\begin{array}{l}\text { Issues to solve related to the } \\
\text { EGTC's operation }\end{array}$ & Yes & Yes & Yes \\
\hline
\end{tabular}

Source: own work.

\section{Internal development determinants}

The organisational structure of all the EGTCs in Poland includes two mandatory bodies (General Meeting and the president). Furthermore, another supervisory authority was introduced in Poland, the supervisory body (Figure 4). The Polish EGTCs, unlike many European EGTCs, did not see the need for establishing problem committees. As for the EGTC Tatry, it was stated that the aim of the members-founders was to develop as simple and uncomplicated structure of its bodies as possible, which would make its operating and making decisions easier. 
FIGURE 4.

\section{EGTC's structure}

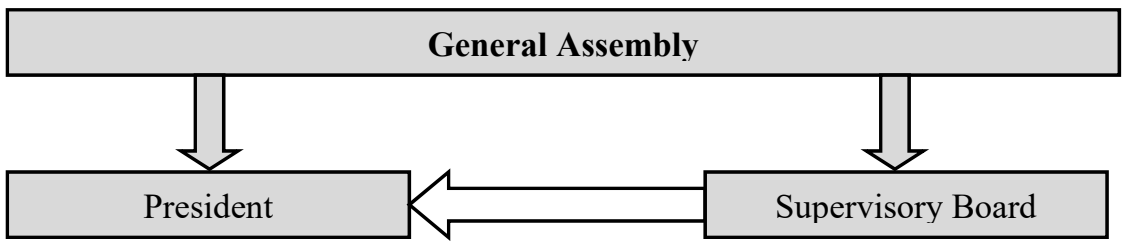

Source: own work based on the convention and statutes of EGTCs.

In three operating EGTCs their members are only regional authorities and associations of local government units. The EU regulation [2006] provided five categories of membership. Due to the amended provisions [EU Regulation, 2013], the number of categories increased to seven. A public entity, university, is planned to be included in this structure in the establishing EGTC. No state has joined an EGTC. EGTCs include 11 entities in total. The cooperation in the planned EGTCs is to cover a bigger number of members (Table 2.).

TABLE 2.

The structure of EGTCs by membership categories

\begin{tabular}{|c|c|c|c|c|c|c|c|c|c|c|}
\hline \multirow[t]{3}{*}{$\begin{array}{c}\text { Category } \\
\text { of membership }\end{array}$} & \multirow{2}{*}{\multicolumn{2}{|c|}{$\begin{array}{l}\text { Regulation } \\
\text { version }\end{array}$}} & \multicolumn{5}{|c|}{ EGTCs } & \multicolumn{3}{|c|}{$\begin{array}{c}\text { Number of } \\
\text { members }\end{array}$} \\
\hline & & & \multicolumn{3}{|c|}{ Existing (E) } & \multicolumn{2}{|c|}{ Planned (P) } & \multirow[t]{2}{*}{$E$} & \multirow[t]{2}{*}{$\mathrm{P}$} & \multirow{2}{*}{$\begin{array}{l}\mathrm{E} \\
+ \\
\mathrm{P}\end{array}$} \\
\hline & 2006 & 2013 & $\begin{array}{l}\text { EGTC } \\
\text { Tatry }\end{array}$ & $\begin{array}{c}\text { EGTC } \\
\text { Tritia }\end{array}$ & $\begin{array}{c}\text { EGTC } \\
\text { ŚKT }\end{array}$ & $\begin{array}{l}\text { EGTC } \\
\text { Novum }\end{array}$ & $\begin{array}{l}\text { EGTC } \\
\text { Trans- } \\
\text { oderana } \\
\end{array}$ & & & \\
\hline EU states & + & + & 0 & 0 & 0 & 0 & 0 & 0 & 0 & 0 \\
\hline States outside the EU & - & + & 0 & 0 & 0 & 0 & 0 & 0 & 0 & 0 \\
\hline Regional government & + & + & 0 & 4 & 5 & 5 & 0 & 9 & 5 & 14 \\
\hline Local government & + & + & 0 & 0 & 0 & 0 & 30 & 0 & 30 & 30 \\
\hline $\begin{array}{l}\text { Selected public law } \\
\text { bodies }\end{array}$ & + & - & 0 & 0 & 0 & 0 & 0 & 0 & 0 & 0 \\
\hline $\begin{array}{l}\text { Selected public law } \\
\text { bodies and public } \\
\text { undertakings }\end{array}$ & - & + & 0 & 0 & 0 & 0 & 1 & 0 & 1 & 1 \\
\hline Selected companies & - & + & 0 & 0 & 0 & 0 & 0 & 0 & 0 & 0 \\
\hline Associations & + & + & 2 & 0 & 0 & 4 & 0 & 2 & 4 & 6 \\
\hline \multicolumn{3}{|c|}{ Total } & 2 & 4 & 5 & 9 & 31 & 11 & 40 & 51 \\
\hline
\end{tabular}

Source: own work based on the convention and statutes of EGTCs

The territorial cooperation of the existing and planned groupings comes down mainly to cross-border cooperation with one or two neighbouring countries (tab. 3.). So far such cooperation has been established only with the Slovak Republic and the Czech Republic. 
The establishment of cooperation with Germany is currently being planned. It should be noted that an EGTC with Lithuania is not planned, which results from complex bilateral relations.

The specificity of the EGTC ŚKT causes that this grouping focuses on interregional cooperation with entities from Sweden and Hungary. This is the only EGTC which is considering to accept new members. Expansion of territorial cooperation gives a possibility to strengthen interregional contacts (even among distant partners) and to adapt the methods of spatial planning and management. On this basis, it is possible to develop wider economic, social and cultural cooperation [http://cetc.pl/index.php?lang=en\&mod=oporozumieniu, (accessed: 22.02.2016)].

TABLE 3.

The EGTCs by states from which their members come from

\begin{tabular}{|l|c|c|c|c|c|c|c|c|}
\hline \multirow{4}{*}{ States } & \multicolumn{4}{|c|}{ EGTCs } & \multicolumn{3}{c|}{ Number of members } \\
\cline { 2 - 8 } & \multicolumn{3}{|c|}{ Existing (E) } & \multicolumn{2}{c|}{ Planned (P) } & E & P & E+P \\
\cline { 2 - 8 } & $\begin{array}{c}\text { EGTC } \\
\text { Tatry }\end{array}$ & $\begin{array}{c}\text { EGTC } \\
\text { Tritia }\end{array}$ & $\begin{array}{c}\text { EGTC } \\
\text { ŚKT }\end{array}$ & $\begin{array}{c}\text { EGTC } \\
\text { Novum }\end{array}$ & $\begin{array}{c}\text { EGTC } \\
\text { Trans- } \\
\text { oderana }\end{array}$ & & & \\
\hline Poland & 1 & 2 & 2 & 3 & 18 & 5 & 21 & 26 \\
Czech Republic & 0 & 1 & 0 & 6 & 0 & 1 & 6 & 7 \\
Germany & 0 & 0 & 0 & 0 & 13 & 0 & 13 & 13 \\
Slovak Republic & 1 & 1 & 0 & 0 & 0 & 2 & 0 & 2 \\
Sweden & 0 & 0 & 1 & 0 & 0 & 1 & 0 & 1 \\
Hungary & 0 & 0 & 2 & 0 & 0 & 2 & 0 & 2 \\
\hline Total & $\mathbf{2}$ & $\mathbf{4}$ & $\mathbf{5}$ & $\mathbf{9}$ & $\mathbf{3 1}$ & $\mathbf{1 1}$ & $\mathbf{4 0}$ & $\mathbf{5 1}$ \\
\hline
\end{tabular}

Source: own work based on the convention and statutes of EGTCs.

Table 4. presents the area of activity of EGTCs. Territorial cooperation developed by the existing EGTCs focuses in the Provinces of Małopolska, Silesia, Opole, and Western Pomerania. Lower Silesia Province and areas from Lubuskie and Wielkopolska Provinces are to join it in the near future. The existing EGTCs comprise an area from $12500 \mathrm{~km}^{2}$ to $230000 \mathrm{~km}^{2}$, so they belong to large groupings.

The priority objectives of EGTCs were established in accordance with the EU guidelines, which provide that an EGTC should develop territorial cooperation in order to increase social, economic and territorial cohesion. In two cases the territorial cooperation was limited to cross-border cooperation. Two EGTCs indicated transport as a priority issue of their activity (Table 5.).

Furthermore, each EGTC determined its detailed objectives and activities. It should be pointed out that all the EGTCs are to support activities related to education, infrastructure and entrepreneurship development, labour market, transport and tourism (Table 6.). Only one EGTC stated that it is not going to handle agriculture, but four EGTCs declared to implement activities to connect cities and towns with villages. One EGTC pointed out the need for the implementation of lobbying. Staff and financial resources are significant factors of EGTC development. 
TABLE 4.

The area of activity and the territory of EGTCs

\begin{tabular}{|c|c|c|c|}
\hline EGTC & The area of activity in Poland & The area of activity abroad & Territory \\
\hline EGTC SKT & $\begin{array}{ll}\text { - } & \text { Western Pomerania } \\
& \text { Province } \\
-\quad & \text { Lubuskie Province }\end{array}$ & $\begin{array}{l}\text { Hungary: } \\
-\quad \text { Komitat Vas, Komitat Zala } \\
\text { Sweden: } \\
-\quad \text { Scania County }\end{array}$ & $230000 \mathrm{~km}^{2}$ \\
\hline EGTC Tatry & - Małopolska Province & $\begin{array}{l}\text { Slovak Republic: } \\
-\quad \text { Districts: Kežmarok, Levoča, } \\
\text { Poprad, Sabinov, Stará Lubovña } \\
\text { in the Prešov Region } \\
\text { - } \quad \text { Districts: Dolný Kubín, } \\
\text { Liptovský Mikuláš, Námestovo, } \\
\text { Ružomberok, Tvrdošín in the } \\
\text { Žilina Region } \\
\text { - Spišská Nová Ves District in } \\
\text { the Košice Region }\end{array}$ & $12500 \mathrm{~km}^{2}$ \\
\hline EGTC Tritia & $\begin{array}{ll}- & \text { Opole Province } \\
- & \text { Silesia Province }\end{array}$ & $\begin{array}{l}\text { Slovak Republic: } \\
-\quad \text { Žilina Region } \\
\text { Czech Republic } \\
-\quad \text { Moravian-Silesian Region }\end{array}$ & $34069 \mathrm{~km}^{2}$ \\
\hline $\begin{array}{l}\text { EGTC } \\
\text { Novum }\end{array}$ & $\begin{array}{l}\text { - } \begin{array}{l}\text { Lower Silesia Province } \\
\text { - }\end{array} \text { The area of municipalities } \\
\text { and districts which are the } \\
\text { members of the Association } \\
\text { of the Polish Municipalities } \\
\text { in the Nysa Euroregion } \\
\text { - The area of municipalities } \\
\text { and districts which are the } \\
\text { members of the Association } \\
\text { of the Polish Municipalities } \\
\text { in the Glacensis Euroregion }\end{array}$ & $\begin{array}{ll}\text { Czech Republic: } \\
-\quad \text { Liberec Region } \\
-\quad \text { Hradec Králové Region } \\
-\quad \frac{\text { Pardubice Region }}{\text { Olomouc Region }} \\
-\quad \text { The area of municipalities and } \\
\text { districts which are the members } \\
\text { of the Association of the Nysa } \\
\text { Euroregion } \\
-\quad \text { The area of municipalities and } \\
\text { districts which are the members } \\
\text { of the Association of the } \\
\text { Glacensis Euroregion }\end{array}$ & $\begin{array}{l}\text { The determination } \\
\text { of the territory will } \\
\text { be possible once } \\
\text { the EGTC has been } \\
\text { registered. The } \\
\text { territory of some } \\
\text { members will } \\
\text { overlap. } \\
\text { The territory will } \\
\text { change along with } \\
\text { changes taking place } \\
\text { in the structure of } \\
\text { Euroregional } \\
\text { associations. }\end{array}$ \\
\hline $\begin{array}{l}\text { EGTC } \\
\text { Transoderana }\end{array}$ & $\begin{array}{l}\text { Wielkopolska Province: } \\
-\quad \text { Czarnków-Trzcianka County } \\
-\quad \text { Towns: Piła, Krzyż Wielko- } \\
\text { polski, Trzcianka, Wieleń } \\
\text { Lubuskie Province } \\
-\quad \text { Gorzów County } \\
-\quad \text { Strzelce-Drezdenko County } \\
-\quad \text { Towns: Gorzów } \\
\text { Wielkopolski, Kostrzyn nad } \\
\text { Odra, Drezdenko, Strzelce } \\
\text { Krajeńskie, Witnica } \\
\text { - Municipalities: Bogdaniec, } \\
\text { Santok, Stare Kurowo, Zwie- } \\
\text { rzyn } \\
\text { Western Pomerania Province } \\
\text { - Wałcz County }\end{array}$ & \begin{tabular}{ll}
\multicolumn{2}{l}{ Germany } \\
$-\quad$ Märkisch-Oderland district \\
$-\quad$ Towns: Buckow, Müncheberg, \\
Seelow Strausberg \\
- $\quad$ Municipalities: Fredersdorf- \\
Vogelsdorf, Golzow, Gusow \\
- Platkow, Hoppegarten, \\
Letschin, Lindendorf, \\
Neuhardenberg, Rehfelde, \\
Vierlinden
\end{tabular} & $\begin{array}{l}\text { The determination } \\
\text { of the territory } \\
\text { will be possible } \\
\text { once the EGTC } \\
\text { has been registered. } \\
\text { The territories of } \\
\text { some members will } \\
\text { overlap. }\end{array}$ \\
\hline
\end{tabular}

Source: own work based on the convention and statutes of EGTCs. 
TABLE 5.

The priority objectives and issues of EGTCs

\begin{tabular}{|c|c|c|}
\hline EGTC & Priority objective & Priority issue \\
\hline EGTC ŚKT & $\begin{array}{l}\text { The facilitation and support of cross-border, transnational and interregional } \\
\text { cooperation within the Central European Transport Corridor, as well as } \\
\text { strengthening economic and social coherence, in particular by the } \\
\text { implementation of projects or programmes of territorial cooperation. }\end{array}$ & $\begin{array}{l}\text { The EGTC's } \\
\text { activity focuses } \\
\text { on road transport } \\
\text { issues. }\end{array}$ \\
\hline $\begin{array}{l}\text { EGTC } \\
\text { Transoderana }\end{array}$ & $\begin{array}{l}\text { The broadening and deepening of Polish-German territorial cooperation, } \\
\text { aimed at strengthening the cross-border communication axis in the area } \\
\text { between Berlin and Piła, in the zone of parallel railway and road connections, } \\
\text { as well as the sections of the Odra, Warta and Noteć rivers corresponding to } \\
\text { them in order to achieve the objectives of the current EU strategy "Europe 2020". }\end{array}$ & $\begin{array}{l}\text { The EGTC's } \\
\text { activity focuses } \\
\text { on rail transport } \\
\text { issues. }\end{array}$ \\
\hline $\begin{array}{l}\text { EGTC } \\
\text { Tatry }\end{array}$ & $\begin{array}{l}\text { The further development, facilitation and dissemination of Polish-Slovak cross- } \\
\text { border cooperation to strengthen economic and social coherence in the } \\
\text { area of the EGTC's activity on the Polish and Slovak side of the Tatras. }\end{array}$ & $\begin{array}{l}\text { No priority issue } \\
\text { has been } \\
\text { determined. }\end{array}$ \\
\hline $\begin{array}{l}\text { EGTC } \\
\text { Tritia }\end{array}$ & $\begin{array}{l}\text { The facilitation and support of cross-border, transnational and interregional } \\
\text { cooperation among its members in order to strengthen economic and } \\
\text { social coherence, in particular by the implementation of the projects or } \\
\text { programmes of territorial cooperation with the following objectives: } \\
\text { 1. to facilitate everyday life for the citizens from the EGTC area; } \\
\text { 2. to create cross-border coherence in the whole area; } \\
\text { 3. to implement projects for joint and strategic development. }\end{array}$ & $\begin{array}{l}\text { No priority issue } \\
\text { has been } \\
\text { determined. }\end{array}$ \\
\hline $\begin{array}{l}\text { EGTC } \\
\text { Novum }\end{array}$ & $\begin{array}{l}\text { The intensification, facilitation and dissemination of Polish-Czech cross- } \\
\text { border cooperation to strengthen economic and social coherence in the } \\
\text { EGTC area. }\end{array}$ & $\begin{array}{l}\text { No priority issue } \\
\text { has been } \\
\text { determined. }\end{array}$ \\
\hline
\end{tabular}

Source: own work based on the convention and statutes of EGTCs.

The economic situation of those EGTCs is difficult but it slowly stabilises. In 2014 the budget of this institution varied from PLN 52593.40 to 279 203. The employment of personnel posed a problem. The EUWT Tritia employed all its staff (president, accounting officer, two project managers) part time. The EUWT SKT employed its personnel (accounting officer, lawyer, translator, IT specialist) based on the contract work. The EUWT Tatry could not employ two people based on the employment contract (its president and project manager) till 2015. It should be pointed out that employing personnel by an EGTC as a legal entity is one of the biggest barriers for all EGTCs in Europe. 
The detailed objectives and tasks of EGTCs

\begin{tabular}{|l|l|c|c|c|c|c|c|}
\hline No. & \multicolumn{1}{|c|}{ Objectives and tasks } & $\begin{array}{c}\text { EGTC } \\
\text { SKT }\end{array}$ & $\begin{array}{c}\text { EGTC } \\
\text { Tatry }\end{array}$ & $\begin{array}{c}\text { EGTC } \\
\text { Tritia }\end{array}$ & $\begin{array}{c}\text { EGTC } \\
\text { Novum }\end{array}$ & $\begin{array}{c}\text { EGTC } \\
\text { Trans- } \\
\text { oderana }\end{array}$ & $\begin{array}{c}\text { Number } \\
\text { of } \\
\text { indications }\end{array}$ \\
\hline 1. & research & + & + & - & + & + & 4 \\
2. & security & - & + & + & + & + & 4 \\
3. & water supply & - & + & + & + & - & 3 \\
4. & education & + & + & + & + & + & 5 \\
5. & energy & - & + & + & + & + & 4 \\
6. & economy & + & - & + & - & + & 3 \\
7. & cross-border trade & - & + & + & + & - & 3 \\
8. & infrastructure & + & + & + & + & + & 5 \\
9. & innovations & + & - & - & + & + & 3 \\
10. & social integration & + & + & - & + & + & 4 \\
11. & culture & - & + & + & + & + & 4 \\
12. & lobbing & + & - & - & - & - & 1 \\
13. & logistics & + & - & - & - & - & 1 \\
14. & connecting cities and towns & - & + & + & + & + & 4 \\
& with villages & & & & & & \\
15. & entrepreneurship & + & + & + & + & + & 5 \\
16. & agriculture & - & - & - & - & + & 1 \\
17. & technological change & + & + & - & + & - & 3 \\
18. & labour market & + & + & + & + & + & 5 \\
19. & sport & - & - & + & - & + & 2 \\
20. & environment & + & + & + & + & + & 5 \\
21. & transport & + & + & + & + & + & 5 \\
22. & tourism & + & + & + & + & + & 5 \\
23. & administrative cooperation & - & + & + & + & - & 3 \\
24. & waste management & - & + & + & + & - & 3 \\
25. & health & - & + & + & + & + & 4 \\
\hline Total & & + & 19 & 18 & 20 & 18 & - \\
\hline
\end{tabular}

Source: own work based on the convention and statutes of EGTCs.

\section{National determinants}

The EGTC activities are governed not only by the EU provisions but also by national provisions [Kusiak-Winter, 2011, pp. 55 - 90]. The rules of establishing EGTCs in Poland were stipulated in an act [Act of 2008]. It was decided that a State may join any EGTC (as one of its members). In this case only the consent of the Council of Ministers is required.

The procedure of joining an EGTC by local government units turned out to be more complex. First, the decision was made by the decision making body of that unit acting by the absolute majority of the statutory number of members. Next, the Minister in charge of foreign affairs gave his consent by a decision, after consultation with the relevant 
Interior Minister, the Minister in charge of public funding and the Minister in charge of regional development, within 3 months from the day of obtaining the resolution or decision (Figure 5.).

The minister in charge of foreign affairs was obliged to keep the Register of the European groupings of territorial cooperation. The contents of the register was regulated by [Regulation 2009].

The registration of an EGTC was made by a person authorised by the members of such EGTC to conduct such activity by attaching:

1. the EGTC's convention and statute;

2. the resolutions or decisions of the EGTC's members on acceptance of the statute;

3. authorisation to conduct activities related to the EGTC's registration;

4. consent of each member to join the EGTC.

The EGTC's convention and statute as well as their amendments were announced in Monitor Sadowy i Gospodarczy free of charge. The announcement was made by the Minister in charge of foreign affairs.

The EGTC was obliged to submit an application to the Committee of the Regions within ten working days from the day of the registration or publication of its convention and statutes. The Committee of the Regions transferred that application to the Publications Office of the European Union in order to publish an announcement about establishing such EGTC in the Official Journal of the European Union, series C.

In 2013 Monitor Polski B was liquidated under the Act on the Reduction of Certain Obligations of Citizens and Businesses [2011]. In Poland the register kept by the Foreign Affairs Minister became an official source of information about EGTCs. There was no refusal to grant consent or register an EGTC by 2014.

In 2015 the Council of Ministers adopted assumptions for the bill on amending the Act on the European grouping of territorial cooperation submitted by the Minister of Infrastructure and Development [http://centrumprasowe.pap.pl/cp/en/news/info/ 24109 , cir-obradowala-rada-ministrow $\% 28$ komunikat $\% 29$; jessionid=jyc+oGI $2 \mathrm{~F} 58$ dz9ZOxzHkiqkN.undefined (accessed: 15.04.2015)].

The rules of the EGTC establishment and operation were clarified and simplified. The proposed amends concern:

1. determining a more detailed procedure of EGTC establishment;

2. the way of joining an EGTC by Polish businesses operating for common good;

3. the implementation of so-called silent procedure (if no decision on giving consent to join an EGTC is issued within 6 months, this will mean the consent to its establishment);

4. specifying the rules of performance in case of amending basic internal documents of an EGTC;

5. the method of record keeping by EGTCs with its registered office in Poland;

6. the clarification of the rules of performance in case of dissolving an EGTC or the infringement of public interest by an EGTC. 
FIGURE 5.

\section{The procedure of establishing an EGTC in Poland}
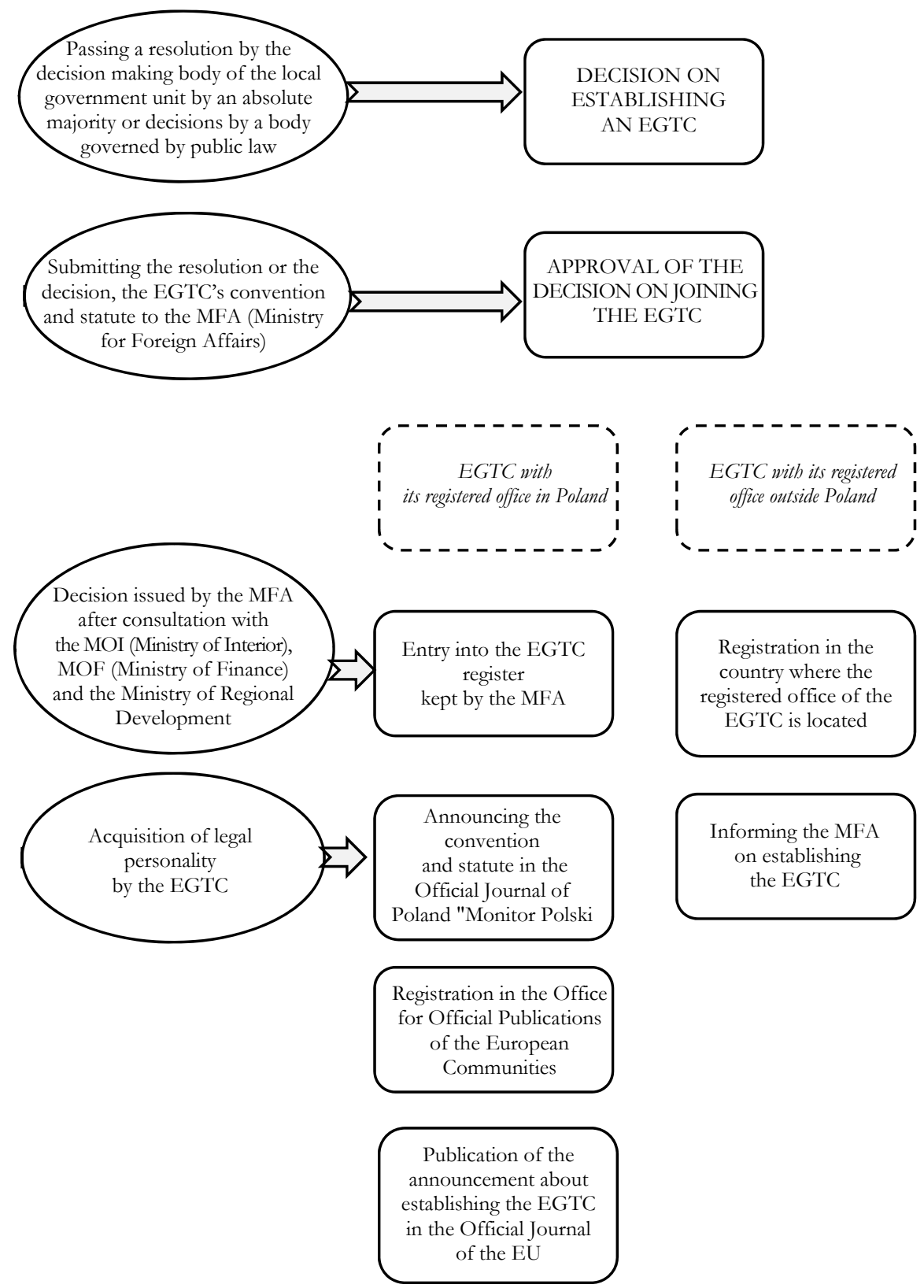

Source: own work based on the information from the EGTC Tatry. 
In Poland the key role in determining the role of an EGTC in the ETC managing programmes is played by the Ministry of Development and Infrastructure (former Ministry of Regional Development). According to the document of the Ministry of Regional Development entitled The Programme of cross-border cooperation with the participation of Poland in the years 2014-2020 [2012]: "Poland welcomes the use of EGTCs as institutions responsible for the implementation of the projects of territorial cooperation. Nevertheless, due to complicated EU provisions on EGTCs and the lack of experience in EGTC activities in Poland, in the years 2014-2020 Poland does not intend to give them a function of the Managing Authority of ETC programmes, but it will encourage to establish EGTCs in order to manage the implementation of such projects."

\section{European determinants}

The EGTC activity is inseparably associated with cohesion policy. The EGTCs whose registered office is located in Poland were established too late to use fully the funds for the development of territorial cooperation during the period between 2006 and 2013. Taking into account the fact that in the period between 2014 and 2020 the European territorial cooperation became one of the two objectives of cohesion policy, the establishment of another EGTCs and the mobilization of the activities of existing EGTCs can be expected.

A new (EU) regulation of the European Parliament and the Council [No 1299/2013] on the European territorial cooperation gives a better control over the international context of the programmes and introduces more detailed provisions on the programmes of cooperation and activities. The need for third countries to be involved was pointed out "in order to reflect the specification of this cooperation". More systematic references to the role, which - in the context of cooperation - the European groupings of territorial cooperation (EGTCs) are to play, were included. A hundred and two programmes in total were provided for the implementation of the objectives and priorities of the European territorial cooperation, including:

1. Interreg VA - 88 programmes, including 60 "internal borders" programmes, 12 "IPA" (Instrument for Pre-accession assistance) programmes, 16 "ENI" (European Neighbourhood Instrument) programmes;

2. Interreg $\mathrm{VB}-15$ programmes;

3. Interreg V C -4 programmes (Interreg Europa, Interact, Urban, Espon).

In respect of the programmes of cross-border cooperation, the EU regions at NUTS 3 level along with all internal and external land borders have been supported. As for the transnational cooperation, the Commission established a list of transnational areas covering the regions at NUTS 2 level, ensuring continued cooperation in bigger and coherent areas, determined based on the previous programmes, including, if necessary, macroregional and marine strategies. The interregional cooperation covered the whole territory of the European Union.

The EGTC programmes dedicated to Poland were presented in Table 7, indicating simultaneously the EGTCs which can use an individual programme. The EGTCs are 
eligible for financing from all the programmes of transnational and interregional cooperation, as well as from the selected programmes of cross-border cooperation.

TABLE 7.

The programmes of European territorial cooperation dedicated to Poland in the years 2014-2020

\begin{tabular}{|c|c|c|c|c|c|}
\hline \multirow{2}{*}{$\begin{array}{c}\text { Type of } \\
\text { programme }\end{array}$} & \multirow[t]{2}{*}{ Programme } & \multirow[b]{2}{*}{\begin{tabular}{|} 
Main priorities of \\
the programme and \\
symbols of \\
investment \\
priorities
\end{tabular}} & \multicolumn{2}{|c|}{ The area covered by [NUTS 3] } & \multirow{2}{*}{$\begin{array}{c}\text { EGTCs } \\
\text { which can } \\
\text { use the } \\
\text { programme }\end{array}$} \\
\hline & & & In Poland & Abroad & \\
\hline \multirow[t]{3}{*}{$\begin{array}{l}\text { Cross- } \\
\text { border }\end{array}$} & $\begin{array}{l}\text { Poland - Slovak } \\
\text { Republic } \\
155 \text { mill. EUR }\end{array}$ & $\begin{array}{ll}\text { 1. } & \begin{array}{l}\text { Environment } \\
\text { (p. 6c) }\end{array} \\
\text { 2. } & \text { Culture (p. 6c) } \\
\text { 3. } & \text { Transport (p. 7bc) } \\
\text { 4. } & \text { Education } \\
& \text { (p. 10b) }\end{array}$ & 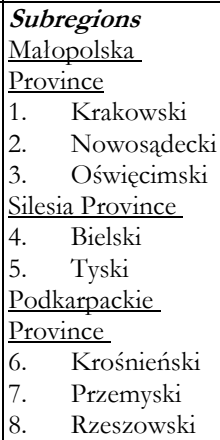 & $\begin{array}{ll}\text { 1. } & \text { Žilina Region } \\
\text { 2. } & \text { Prešov Region } \\
\text { 3. } & \text { Košice Region }\end{array}$ & $\begin{array}{ll}\text { 1. } & \text { EGTC } \\
& \text { Tatry } \\
\text { 2. } & \text { EGTC } \\
& \text { Tritia }\end{array}$ \\
\hline & $\begin{array}{l}\text { Czech Republic } \\
\text { - Poland } \\
226 \text { mill. EUR }\end{array}$ & 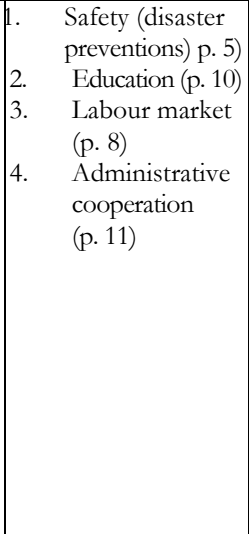 & 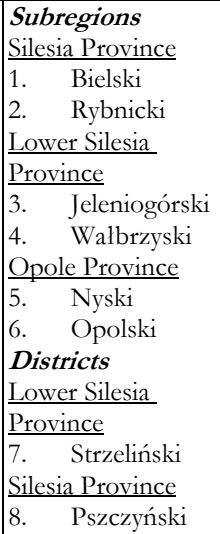 & \begin{tabular}{|ll} 
1. & Liberec Region \\
2. & Hradec \\
Králové \\
Region \\
3. & $\begin{array}{l}\text { Pardubice } \\
\text { Region } \\
\text { 4. }\end{array}$ \\
Olomouc \\
Region \\
5. & $\begin{array}{l}\text { Moravian- } \\
\text { Silesian Region }\end{array}$
\end{tabular} & $\begin{array}{l}\text { EGTC Tritia } \\
\text { EGTC } \\
\text { Novum }\end{array}$ \\
\hline & $\begin{array}{l}\text { Poland-Saxony } \\
70 \text { mill. EUR }\end{array}$ & $\begin{array}{ll}\text { 1. } & \begin{array}{l}\text { Environment } \\
\text { (p. 6c) }\end{array} \\
\text { 2. } & \text { Culture (p. 6c) } \\
\text { 3. } & \text { Education (p. 10) } \\
\text { 4. } & \text { Transport (p. 7bc) } \\
\text { 5. } & \text { Administrative } \\
& \begin{array}{l}\text { cooperation } \\
\text { (p. 11) }\end{array}\end{array}$ & $\begin{array}{l}\text { Subregions } \\
\text { Lower Silesia } \\
\text { Province } \\
1 . \quad \text { Jeleniogórski } \\
\text { Districts } \\
\text { Lubuskie Province } \\
2 . \quad \text { Zarski }\end{array}$ & $\begin{array}{ll}\text { 1. } & \text { Görlitz district } \\
\text { 2. } & \begin{array}{l}\text { Bautzen } \\
\text { district }\end{array}\end{array}$ & \\
\hline
\end{tabular}




\begin{tabular}{|c|c|c|c|c|c|}
\hline $\begin{array}{l}\text { Brandenburg- } \\
\text { Poland } \\
100 \text { mill. EUR }\end{array}$ & \begin{tabular}{|ll} 
1. & Administrative \\
& cooperation $(\mathrm{p}$. \\
& $11)$ \\
2. & Education (p. 10) \\
3. & $\begin{array}{l}\text { Environment } \\
\text { (p. } 6 \mathrm{~cd})\end{array}$ \\
4. & Culture (p. 6cd) \\
5. & Transport \\
& $(7 . \mathrm{bc})$
\end{tabular} & 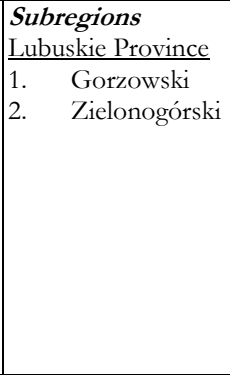 & 2. & $\begin{array}{l}\text { Märkisch- } \\
\text { Oderland } \\
\text { district } \\
\text { Oder-Spree } \\
\text { district } \\
\text { Spree-Neiße } \\
\text { district } \\
\text { the City of } \\
\text { Frankfurt } \\
\text { (Oder) } \\
\text { the City of } \\
\text { Cottbus }\end{array}$ & $\begin{array}{l}\text { EGTC } \\
\text { Trans- } \\
\text { oderana }\end{array}$ \\
\hline $\begin{array}{l}\text { Mecklenburg- } \\
\text { Western } \\
\text { Pomerania- } \\
\text { Brandenburg- } \\
\text { Poland } \\
134 \text { mill. EUR }\end{array}$ & \begin{tabular}{|ll} 
1. & $\begin{array}{l}\text { Administrative } \\
\text { cooperation }\end{array}$ \\
(p. 11$)$ \\
2. & Education (p. \\
& 10) \\
3. & Transport (7.b) \\
4. & $\begin{array}{l}\text { Environment } \\
\text { (p. } 6 \mathrm{~cd})\end{array}$ \\
5. & Culture (p. 6c)
\end{tabular} & 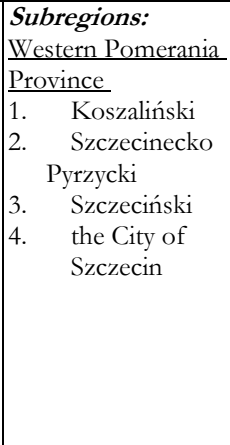 & $\begin{array}{l}1 . \\
2 . \\
3 .\end{array}$ & $\begin{array}{l}\text { Barnim district } \\
\text { Uckermark } \\
\text { district } \\
\text { Märkisch- } \\
\text { Oderland } \\
\text { district } \\
\text { Vorpommern- } \\
\text { Rügen district } \\
\text { Vorpommern- } \\
\text { Greifswald } \\
\text { district } \\
\text { Mecklenburgis } \\
\text { che Seenplatte } \\
\text { district }\end{array}$ & \\
\hline $\begin{array}{l}\text { Southern Baltic } \\
\text { Sea } \\
83 \text { mill. EUR }\end{array}$ & $\begin{array}{ll}\text { 1. } & \begin{array}{l}\text { Entrepreneurship } \\
\text { (p. 3bc) }\end{array} \\
\text { 2. } & \begin{array}{l}\text { Environment } \\
\text { (p. 6 c) }\end{array} \\
\text { 3. } & \text { Culture (p. 6c) } \\
\text { 4. } & \text { Waste mana- } \\
& \text { gement (p. 6f) } \\
\text { 5. } & \text { Transport (p. 7c) } \\
\text { 6. } & \text { Labour market } \\
& \text { (p. 8) } \\
\text { 7. } & \text { Administrative } \\
& \text { cooperation } \\
& \text { (p. 11) }\end{array}$ & 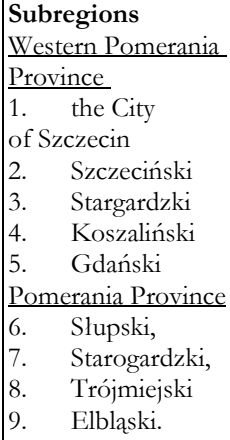 & \multicolumn{2}{|c|}{$\begin{array}{l}\text { The coastal areas of } \\
\text { Lithuania, Denmark, } \\
\text { Sweden and } \\
\text { Germany }\end{array}$} & \\
\hline $\begin{array}{l}\text { Lithuania- } \\
\text { Poland) } \\
51.5 \text { mill. EUR }\end{array}$ & \begin{tabular}{|ll} 
1. & $\begin{array}{l}\text { Environment } \\
\text { (p. 6c) }\end{array}$ \\
2. & Culture (p. 6c) \\
3. & $\begin{array}{l}\text { Labour market } \\
\text { (p. 8) }\end{array}$ \\
4. & $\begin{array}{l}\text { Social integration } \\
\text { (p. 9a) }\end{array}$ \\
5. & $\begin{array}{l}\text { Administrative } \\
\text { cooperation } \\
\text { (p. 11) }\end{array}$ \\
\end{tabular} & $\begin{array}{ll}\text { Subregions } \\
\text { Warmia-Mazuria } \\
\text { Province } \\
\text { 1. } & \text { Ełcki } \\
\text { Podlasie Province } \\
2 . & \text { Suwalski } \\
\text { 3. } & \text { Białostocki }\end{array}$ & 2. & $\begin{array}{l}\text { Alytus County } \\
\text { Marijampole } \\
\text { County } \\
\text { Kaunas } \\
\text { County } \\
\text { Taurage } \\
\text { County } \\
\text { Vilnius County } \\
\text { (without the } \\
\text { City of Vilnius) } \\
\end{array}$ & \\
\hline
\end{tabular}




\begin{tabular}{|c|c|c|c|c|c|}
\hline \multirow[t]{2}{*}{\begin{tabular}{|l} 
Trans \\
national
\end{tabular}} & $\begin{array}{l}\text { Baltic Sea } \\
\text { Region } \\
264 \text { mill. EUR }\end{array}$ & \begin{tabular}{|ll} 
1. & Research (p. 1ab) \\
2. & Innovations \\
& (p. 1ab) \\
3. & $\begin{array}{l}\text { Technological } \\
\text { change (p. 1ab) }\end{array}$ \\
4. & Economy (p. 6g) \\
5. & $\begin{array}{l}\text { Environment } \\
\text { (p. 6bg) }\end{array}$ \\
6. & Transport \\
& (p. 7bc) \\
6. & Administrative \\
& cooperation \\
& (p. 11)
\end{tabular} & $\begin{array}{l}\text { The area of the } \\
\text { whole country }\end{array}$ & $\begin{array}{l}\text { Denmark, Sweden, } \\
\text { Finland, Lithuania, } \\
\text { Latvia, Estonia, } \\
\text { Germany (selected } \\
\text { regions), Norway, } \\
\text { Belarus, Russia } \\
\text { (selected regions) }\end{array}$ & All EGTCs \\
\hline & $\begin{array}{l}\text { Central Europe } \\
246 \text { mill. EUR }\end{array}$ & \begin{tabular}{|ll} 
1. & $\begin{array}{l}\text { Research (p. 1b) } \\
\text { 2. }\end{array}$ \\
Innovations \\
(p. 1b)
\end{tabular} & $\begin{array}{l}\text { The area of the } \\
\text { whole country }\end{array}$ & $\begin{array}{l}\text { Austria, Croatia, } \\
\text { Czech Republic, } \\
\text { Poland, Slovak } \\
\text { Republic, Slovenia, } \\
\text { Hungary, Germany } \\
\text { (selected regions) } \\
\text { Italy (selected } \\
\text { regions) }\end{array}$ & All EGTCs \\
\hline \begin{tabular}{|l} 
Inter \\
regional
\end{tabular} & $\begin{array}{l}\text { Interreg Europa } \\
359 \text { mill. EUR }\end{array}$ & 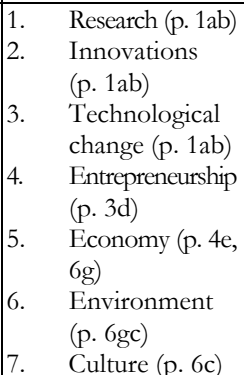 & $\begin{array}{l}\text { The area of the } \\
\text { whole country }\end{array}$ & $\begin{array}{l}\text { European Union, } \\
\text { Norway and } \\
\text { Switzerland }\end{array}$ & All EGTCs \\
\hline
\end{tabular}

Source: own work.

The compliance of the investment priorities of individual programmes with the objectives and tasks which the EGTCs included in their documents should be pointed out (Table 8.). It means that the EGTCs are well-prepared to absorb the funds from ETC programmes. 
TABLE 8.

The investment priorities of ETC programmes in view of the objectives and tasks of EGTCs

\begin{tabular}{|c|c|c|c|c|c|}
\hline Programme & EGTC SKT & EGTC Tatry & EGTC Tritia & EGTC Novum & \begin{tabular}{|l|} 
EGTC \\
Transoderana
\end{tabular} \\
\hline Cross-border & & $\begin{array}{ll}\text { Poland - Slovak } \\
\text { Republic } \\
\text { Programme: } \\
\text { 1. } & \text { Environment } \\
\text { 2. } & \text { Culture } \\
\text { 3. } & \text { Transport } \\
\text { 4. } & \text { Education }\end{array}$ & 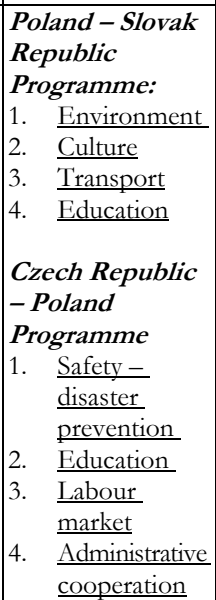 & $\begin{array}{ll}\text { Czech Republic } \\
\text { - Poland } \\
\text { Programme } \\
\text { 1. } \frac{\text { Safety - }}{\text { disaster }} \\
\text { 2. } & \underline{\text { prevention }} \\
\text { 3. } & \underline{\text { Labouration }} \\
\text { 4. } & \underline{\text { market }} \\
& \underline{\text { Administrative }} \\
\end{array}$ & $\begin{array}{l}\text { Brandenburg- } \\
\text { Poland } \\
\text { Programme } \\
\text { 1. Administrative } \\
\text { cooperation } \\
\text { 2. Education } \\
\text { 3. Environment } \\
\text { 4. } \text { Culture } \\
\text { 5. } \text { Transport }\end{array}$ \\
\hline $\begin{array}{l}\text { Transnational } \\
\text { RMB } \\
\text { Programme }\end{array}$ & $\begin{array}{ll}\text { 1. } & \text { Research } \\
\text { 2. } & \text { Innovations } \\
\text { 3. } & \text { Development } \\
\text { 4. } & \text { of technology } \\
\text { 5. } & \text { Environment } \\
\text { 6. } & \text { Transport } \\
\text { 7. } & \text { Administrative } \\
& \text { cooperation }\end{array}$ & $\begin{array}{ll}\text { 1. } & \text { Research } \\
\text { 2. } & \text { Innovations } \\
\text { 3. } & \text { Development } \\
\text { 4. } & \text { of technology } \\
\text { 5. } & \text { Environment } \\
\text { 6. } & \text { Transport } \\
\text { 7. } & \text { Administrative } \\
& \text { cooperation }\end{array}$ & $\begin{array}{ll}\text { 1. } & \text { Research } \\
\text { 2. } & \text { Innovations } \\
\text { 3. } & \text { Development } \\
\text { 4. } & \text { of technology } \\
\text { 5. } & \text { Economy } \\
\text { 6. } & \text { Transport } \\
\text { 7. } & \text { Administrativ } \\
& \text { e cooperation } \\
\end{array}$ & $\begin{array}{ll}\text { 1. } & \text { Research } \\
\text { 2. } & \text { Innovations } \\
\text { 3. } & \text { Development } \\
\text { 4. } & \text { of technology } \\
\text { 5. } & \text { Environomy } \\
\text { 6. } & \text { Transport } \\
\text { 7. } & \text { Administrative } \\
& \text { cooperation }\end{array}$ & $\begin{array}{ll}\text { 1. } & \text { Research } \\
\text { 2. } & \text { Innovations } \\
\text { 3. } & \text { Development } \\
\text { 4. } & \text { of technology } \\
\text { 5. } & \text { Environment } \\
\text { 6. } & \text { Transport } \\
\text { 7. } & \text { Administrative } \\
& \text { cooperation }\end{array}$ \\
\hline \begin{tabular}{|l|} 
Central \\
Europe \\
Transnationa \\
l Programme
\end{tabular} & $\begin{array}{ll}\text { 1. } & \text { Research } \\
\text { 2. } & \text { Innovations } \\
\text { 3. } & \text { Technological } \\
\text { 4. } & \text { change } \\
\text { 5. } & \text { Environment } \\
\text { 6. } & \text { Transport }\end{array}$ & \begin{tabular}{|ll} 
1. & Research \\
2. & Innovations \\
3. & Technological \\
4. & Ehange \\
5. & Enviromy \\
6. & Transport
\end{tabular} & \begin{tabular}{|ll} 
1. & Research \\
2. & Innovations \\
3. & Technological \\
& change \\
4. & Economy \\
5. & Environment \\
6. & Transport
\end{tabular} & \begin{tabular}{|ll} 
1. & Research \\
2. & Innovations \\
3. & Technological \\
4. & change \\
5. & Economy \\
6. & Tranvironment \\
\end{tabular} & $\begin{array}{ll}\text { 1. } & \text { Research } \\
\text { 2. } & \text { Innovations } \\
\text { 3. } & \begin{array}{l}\text { Technological } \\
\text { change }\end{array} \\
\text { 4. } & \text { Entrepreneur- } \\
\text { 5. } & \text { Ehip } \\
\text { 6. } & \text { Transironment } \\
\text { Transport }\end{array}$ \\
\hline $\begin{array}{l}\text { Inter } \\
\text { regional } \\
\text { Programme }\end{array}$ & $\begin{array}{ll}\text { 1. } & \text { Research } \\
\text { 2. } & \text { Innovations } \\
\text { 3. } & \text { Technological } \\
\text { 4. } & \text { Ehange } \\
\text { Entrepreneur- } \\
\text { 5. } & \text { ship } \\
\text { 6. } & \text { Environment } \\
\text { 7. } & \text { Culture }\end{array}$ & $\begin{array}{ll}\text { 1. } & \text { Research } \\
\text { 2. } & \text { Innovations } \\
\text { 3. } & \text { Technological } \\
\text { 4. } & \text { change } \\
\text { Entrepreneur- } & \text { ship } \\
\text { 5. } & \text { Economy } \\
\text { 6. } & \text { Environment } \\
\text { 7. } & \text { Culture }\end{array}$ & \begin{tabular}{|ll} 
1. & Research \\
2. & Innovations \\
3. & $\begin{array}{l}\text { Technological } \\
\text { change }\end{array}$ \\
4. & Entrepreneur- \\
5. & ship \\
6. & Environment \\
7. & Culture
\end{tabular} & $\begin{array}{ll}\text { 1. } & \text { Research } \\
\text { 2. } & \text { Innovations } \\
\text { 3. } & \text { Technological } \\
\text { change } \\
\text { 4. } & \text { Entrepreneur } \\
& \text { ship } \\
\text { 5. } & \text { Economy } \\
\text { 6. } & \text { Environment } \\
\text { 7. } & \text { Culture }\end{array}$ & $\begin{array}{ll}\text { 1. } & \text { Research } \\
\text { 2. } & \text { Innovations } \\
\text { 3. } & \begin{array}{l}\text { Technological } \\
\text { change }\end{array} \\
\text { 4. } & \text { Entrepreneur } \\
\text { 5. } & \text { ship } \\
\text { 6. } & \text { Envonomy } \\
\text { 7. } & \text { Culture }\end{array}$ \\
\hline
\end{tabular}

Source: own work.

Connecting the ETC priorities with EGTC activities is one of the most important criteria of successful cohesion policy. 


\section{Conclusions}

The EGTC is a pioneering but not fully working EU legal instrument. There are serious barriers both on the registration stage and on the stage of managing this institution. There is a lack of understanding of what an European grouping of territorial cooperation is, what characteristics it has and what role it should play, taking into account its crossborder identity. This issue concerns the institutions involved in the programmes of the European Cooperation at national, regional and local level.

It should be noted that the European Union intended to develop a new dimension of territorial cooperation. This new instrument has become an opportunity for regions and towns located in the border area. Soon, it will be possible to use the EGTC instrument in the cooperation with Russia, Ukraine and Belarus.

Practically, the position of the Polish EGTCs in view of EU regulations on EGTCs and the programmes of the European territorial cooperation has been marginalised. The establishment of an EGTC in Poland requires "to pave the way", convince law makers and dispel the doubts about its international status.

A considerable success has been already achieved thanks to the determination of the founders of EGTCs as well as their organisational and financial involvement. All the EGTCs have established efficient structures, clearly determined their objectives and tasks. They have drawn up or are drawing up their development strategies, including the use of EU funds. The first Polish EGTC, Tritia, is perceived as a "pioneering entity of cross-border relations" and a "model example of cooperation" [Adamczuk, 2014, p. 19].

National institutions still have a lot of power to limit the EGTC competencies. The government administration authorities must be convinced to gradually assign their rights to EGTCs in accordance with the intention of the European Union. The foreign policy of a country may facilitate the EGTC development if it results in removing barriers which still occur in relations with neighbouring states. In neighbouring states there is mistrust of EGTCs (in particular when the registered office is located in Poland).

It should be emphasised that despite the barriers which occur not only in Poland but in other countries, a new, promising system of transnational cooperation has been developed in Europe. When external conditions improve, it will allow for taking a significant step to achieve the most important ETC's objective, which is social and economic coherence in Europe.

\section{References}

Act on the European grouping of territorial cooperation of 7 November 2008, Dz. U. of 2008, No 218, item 1390.

Act on the Reduction of Certain Obligations of Citizens and Businesses of 16 September 2011, Dz. U. of 2011, No 232, item 1378.

Adamczuk F. 2014 Tritia - nowa forma i instytucja integracji europejskiej, „Prace Naukowe Uniwersytetu Ekonomicznego we Wrocławiu", No. 367. 
Buczkowski L., Żukowski L. J., 2014, Formy wspótpracy międzynarodowej lokalnych jednostek samorzqdu terytorialnego, [in:] 10 lat doswiadczeń polskiego samorzqdu terytorialnego w Unii Europejskiej, (ed.) E. Feret, P. Niemczuk, Wyższa Szkoła Prawa i Administracji, Przemyśl.

Council Regulation (EC) No 1083/2006 of 11 July 2006 laying down general provisions on the European Regional Development Fund, European Social Fund and Cohesion Fund and repealing Regulation (EC) No 1260/1999.

Dołzbłasz S., Raczyk A., 2010, Wspótpraca transgraniczna w Polsce po akecesji do UE, Oficyna Wolters Kluwer business, Warszawa.

Dumała H., 2009, Wspótpraca międzyterytorialna w prawie Wspólnot Europejskich, „Annales Universitatis Mariae Curie-Skłodowska”, Sectio K, Politologia, Vol. 16, 1.

http://centrumprasowe.pap.pl/cp/en/news/info/24109,,cir-obradowala-radaministrow $\% 28 \mathrm{komunikat} \% 29$;jsessionid=jyc + oGI2F58dz9ZOxzHkiqkN.undefi ned (accessed: 15.04.2015).

http:/ / cetc.pl/index.php?lang =en\&mod= oporozumieniu (accessed: 22.02.2016).

Jóskowiak K., 2013, Europejskie Ugrupowanie Wspótpracy Terytorialnej - innowacyjny instrument polityki spójności Unii Europejskiej [in:] Polsko Stowacka W spótpraca Transgraniczna Samorzqdón Lokalnych w latach 2012-2013, Związek Euroregion ,"Tatry” in Nowy Targ, Nowy Targ.

Kasprzyk M., 2004, Program wspótpracy praygranicznej PHARE Polska-Niemcy w kontekśsie inicjatywy wspólnotowej Interreg II, [in:] Współpraca transgraniczna Unii Europejskiej - doświadczenia polsko-niemieckie, (ed.) G. Gorzelak, J. Bachtler, M. Kasprzyk, Wydawnictwo Naukowe "Scholar", Warszawa.

Kentnowska K., 2012, Rozwój form wspótpracy samorzadów na poziomie międzynarodowym, [in:] Formy wspótdrialania jednostek samorzqdu terytorialnego, (ed.) B. Dolnicki, Lex a Wolters Kluwer business, Warszawa.

Kusiak-Winter R., 2011, Współpraca transgraniczna gmin Polski i Niemiec studium administracyjnoprawne, Prace Naukowe Wydziału Prawa, Administracji i Ekonomii Uniwersytetu Wrocławskiego, Wrocław.

Ładysz J., 2011, Europejskie ugrupowania wspótpracy terytorialnej - od konkurowania do integracji transgranicznej, [in:] Uwarunkowania i instrumenty polityki rozwoju regionalnego w warunkach integracji europejskiej i swiatowego kryzysu gospodarczego, (ed.) Z. Mikołajewicz, Wydawnictwo Uniwersytetu Opolskiego, Opole.

Lewkowicz L., 2013, Europejskie ugrupowania wspótpracy terytorialnej - nowa jakość polskostowackiej współpracy transgranicznej?, „Studia Regionalne i Lokalne”, No. 1(51).

Luks K., 2012, Polityka gospodarcza - nauka czy praktyka, Maritime Institute in Gdańsk, Gdańsk.

Mędza A., 2014, EUWT - nowy wymiar współpracy transgranicznej, „Prace Naukowe Wałbrzyskiej Wyższej Szkoły Zarządzania i Przedsiębiorczości”, No. 3 (280).

Międzynarodowa wspótpraca regionów, 1997, (ed.) W. Toczyski, W. Sartorius, J. Zaucha, Warszawa

Mikołajczyk A., 2005, Regiony transgraniczne i współpraca transgranična, [in:] Regiony, (ed.) Z. Brodecki, LexisNexis, Warszawa. 
Pancer-Cybulska E., 2015, Europejskiej Ugrupowania W spótpracy EUWT w pakiecie legislacyjnym na okres programowania 2014-2010, „Prace Naukowe Uniwersytetu Ekonomicznego we Wrocławiu", No. 380.

Programme of cross-border cooperation with the participation of Poland in the years 2014-2020, document of the Ministry of Regional Development of 25.09.2012.

Proniewski M., 2008, Europejska wspótpraca międzynarodowa i praygraniczna w gospodarce regionalnej i lokalnej, [in:] Gospodarka regionalna i lokalna, (ed.) Z. Strzelecki, PWN, Warszawa.

Regulation (EU) No 1299/2013 of the European Parliament and the Council of 17 December 2013 on specific provisions on the support from the European Regional Development Fund to the "European territorial cooperation goal" Dz. U. EU L $347 / 259$.

Regulation (EU) No 1302/2013 of the European Parliament and the Council of 17 December 2013 and amending Regulation (EC) No 1082/2006 on the European grouping of territorial cooperation (EGTC) as regards the clarification, simplification and improvement of the establishment and implementation of such groupings.

Regulation of the Foreign Affairs Minister of 17 July 2009 on the method of keeping the Register of the European groupings of territorial cooperation, Dz. U. of 2009, No 105, item 875.

Ruszkowski J., 2010, Ponadnarodowośc w systemie politycznym Unii Europejskiej, Oficyna a Wolters Kluwer business, Warszawa.

Schoutheete P., 1999, Europa dla wszystkich, Wydawnictwo Interpress, Warszawa.

Ślusarz B., 2014, Euroregion „Sprewa-Nysa-Bóbr” w perspektymie finansowej 2014-2020, diagnoza orazplan działania i rozwoju, [in:] W spółczesne problemy rozwoju regionalnego, (ed.) B. Ślusarz, J. Wyrwa, Polskie Towarzystwo Ekonomiczne w Zielonej Górze, Zielona Góra. Studzieniecki T., 2015, Europejskie Ugrupowania Wspótpracy Terytorialnej - ujecie podmiotowe, przedmiotowe i przestrzenne, Academia Europa Nostra, Lubieszynek. 